\title{
GAYA BAHASA DALAM WACANA IKLAN PRODUK KOSMETIK DI FACEBOOK
}

\author{
Rini Damayanti \\ Universitas Wijaya Kusuma Surabaya \\ Jl. Dukuh Kupang XXV/54 Kota Surabaya, Indonesia \\ Pos-el : $\underline{\text { rinidamayanti_fbs@uwks.ac.id }}$
}

\begin{abstract}
This language about the style of language by focusing discourse cosmetic products in facebook advertising. In this research methods in a descriptive qualitative. The data obtained from facebook. The purpose of this research to described use of language. The result of this research described the language used in cosmetics in facebook advertising a product in the force in terms of language covering on climax, anticlimax and repetitions.
\end{abstract}

Keywords: style of language, advertising , facebook

\section{Abstrak}

Penelitian bahasa ini tentang gaya bahasa dengan memfokuskan wacana iklan produk kosmetik di facebook. Metode dalam penelitian ini menggunakan metode deskriptif kualitatif. Data penelitian diperoleh dari media sosial facebook. Tujuan penelitian ini untuk mendeskripsikan penggunaan gaya bahasa. Hasil penelitian ini mendeskripsikan gaya bahasa yang digunakan dalam iklan produk kosmetik di facebook memakai gaya klimaks, antiklimaks, dan repetisi.

Kata Kunci : gaya bahasa, iklan, facebook

\section{PENDAHULUAN}

Bahasa merupakan hal yang penting dan berperan besar dalam kehidupan sosial manusia karena bahasa merupakan alat untuk berkomunikasi antara manusia satu dengan yang lain. Satu di antara sistem komunikasi manusia modern, yang berkembang adalah media sosial. Media sosial saat ini menjadi sarana komunikasi yang memiliki peran besar dan luas dalam menyebarkan informasi ke semua masyarakat di Indonesia. Perkembangan media sosial di Indonesia mempunyai manfaat yang positif dan negatif dalam penggunaannya. Banyaknya media sosial yang hadir di dunia maya membuat semua orang dapat berinteraksi kepada orang satu ke yang lain dalam berbeda tempat, ataupun membaca dan melihat berita yang sedang terjadi dimana pun. 
Media sosial merupakan situs dunia yang terhubung dengan layanan internet, satu diantaranya Facebook. Pada zaman globalisasi seperti ini banyak yang dapat menggunakan media sosial tersebut karena dengan mudahnya internet yang dapat dijangkau dan menjadi alat komunikasi yang sering ditemui oleh semua kalangan. Informasi mengenai barang atau jasa dapat dengan mudah diketahui melalui iklan yang diinfokan.

Iklan pada dasarnya bentuk komunikasi nonpersonal yang disampaikan lewat media sosial untuk menyampaikan pesan yang berkepentingan kepada masyarakat Indonesia. Efek yang diharapkan dari karakteristik bahasa maupun tuturan bahasa iklan yaitu supaya orang tertarik pada produk atau jasa tersebut. Setiap bahasa iklan harus diperhatikan terutama pada pemilihan kata dan gaya bahasa karena yang selalu ditonjolkan, yaitu kelebihan dari produk yang diiklankan baik khasiat, bahan maupun penggunaannya.

Periklanan dirancang untuk mempromosikan dan memperkenalkan produk-produk baru dari masyarakat satu ke masyarakat yang lain. Periklanan menyebabkan perubahan dalam gaya hidup dan pola perilaku. Produk yang banyak ditawarkan misalnya produk makanan cepat saji, pakaian kasual, kesehatan dan produk kecantikan.

Jika mengamati iklan-iklan yang selalu muncul dalam media sosial, sering ditampilkan produk perawatan kecantikan untuk wanita yaitu kosmetik. Zaman sekarang banyak wanita yang memakai kosmetik untuk mempercantik dirinya supaya bisa tampil tetap awet muda dan cantik di mata orang lain. Mereka pun tidak melihat umur terutama para gadis remaja.

Semakin banyak yang memakai kosmetik di kalangan masyarakat, dapat dilihat produkproduk kecantikan ditemui dengan mudah dengan berbagai merk, seperti Pond's, Wardah, Maybeline, Oriflame. Oleh karena itu, produsen iklan kosmetik selalu menampilkan model cantik, menarik, dan populer sehingga bisa menambah kepercayaan akan produk tersebut, yang akhirnya mampu memikat sasaran khayalak untuk membeli produk yang diiklankan di sosial media, serta didukung pemakaian gaya bahasanya yang menjanjikan sehingga akan menambah ketertarikan para wanita.

Berdasarkan latar belakang tersebut, penelitian ini bertujuan untuk melakukan pengamatan terhadap iklan kosmetik karena termasuk salah satu jenis produk yang sering diiklankan dimana- 
mana dan mudah ditemui. Hal ini tidak terlepas dari target pasar yang terutama ditujukan untuk wanita di Indonesia, karena para wanita sebagai target pasar yang paling besar untuk masalah produk kosmetik.

Gaya bahasa dalam retorika dikenal dengan istilah style. Kata "Style" diturunkan dari bahasa latin "stylus". Yaitu semacam alat untuk menulis pada lempengan lilin. Pada perkembangan berikutnya, kata style lalu berubah menjadi kemampuan dan keahlian untuk menulis atau mempergunakan katakata secara indah (Keraf, 2008:112). Secara singkat (Tarigan, 2013:4) mengemukakan bahwa gaya bahasa merupakan bentuk retorik, yaitu penggunaan kata-kata dalam berbicara dan menulis untuk meyakinkan atau mempengaruhi penyimak atau pembaca.

Majas sering dianggap sebagai sinonim dari gaya bahasa, namun sebenarnya majas termasuk dalam gaya bahasa. Sebelum masuk pada pembahasan tentang majas, terlebih dahulu akan dikemukakan pengertian tentang gaya bahasa. Gaya bahasa mempunyai cakupan yang sangat luas. Menurut penjelasan Kridalaksana (2008), gaya bahasa (style) mempunyai tiga pengertian, yaitu:

1. Pemanfaatan atas kekayaan bahasa oleh seseorang dalam bertutur atau menulis.
2. Pemakaian ragam tertentu untuk memperoleh efek-efek tertentu.

3. Keseluruhan ciri-ciri bahasa sekelompok penulis sastra.

Pengertian gaya bahasa dari ketiga ahli tersebut tidak tampak adanya perbedaan yang mendasar, bahkan ketiga pendapat tersebut semakin memperjelas konsep dari gaya bahasa itu sendiri. Dengan demikian, dapat disimpulkan bahwa gaya bahasa adalah pengaturan kata-kata dan kalimatkalimat oleh penulis atau pembaca dalam mengekspresikan ide, gagasan, dan pengalamannya untuk meyakinkan atau mempengaruhi penyimak atau pembaca.

Gaya bahasa dapat berdasarkankan struktur kalimat. Struktur kalimat yang dimaksud adalah kalimat bagaimana tempat sebuah unsur kalimat yang dipentingkan dalam kalimat tersebut. Ada kalimat yang bersifat periodik, bersifat kendur, dan kalimat berimbang. Berdasarkan ketiga macam struktur kalimat tersebut gaya-gaya bahasa sebagai berikut :

a) Klimaks adalah semacam gaya bahasa yang mengandung urutan-urutan pikiran yang setiap kali semakin meningkat kepentingannya.

b) Antiklimaks sebagai gaya bahasa merupakan suatu acuan yang gagasan-gagasannya diurutkan dari yang terpenting berturut- 
turut ke gagasan yang kurang penting.

c) Paralelisme adalah semacam gaya bahasa yang berusaha mencapai kesejajaran dalam pemakaian kata-kata atau frasafrasa yang menduduki fungsi yang sama dalam bentuk gramatikal yang sama.

d) Antitesis adalah sebuah gaya bahasa yang mengandung gagasan-gagasan yang bertentangan, dengan mempergunakan kata-kata atau kelompok kata yang berlawanan.

e) Repetisi adalah perulangan bunyi, suku kata, kata atau bagian kalimat yang dianggap penting untuk memberi tekanan dalam sebuah konteks yang sesuai.

\section{Widyatama}

mengartikan iklan sebagai bentuk kegiatan komunikasi non-personal yang disampaikan lewat media dengan membayar ruang yang dipakainya untuk menyampaikan pesan yang bersifat membujuk (persuasif) kepada konsumen oleh perusahaan, lembaga nonkomersial, maupun pribadi yang berkepentingan. Iklan merupakan berita pesanan untuk mendorong, membujuk khayalak ramai agar tertarik pada barang dan jasa yang ditawarkan.

Menurut Bittner (dalam Widyatama, 2009) ada 2 jenis iklan yaitu iklan standar dan iklan layanan masyarat. Iklan standar yaitu iklan yang ditata secara khusus untuk keperluan memperkenalkan barang, jasa, pelayaan untuk konsumen melalui media periklanan. Tujuan iklan standar yaitu merangsang motif dan minat para pembeli atau pemakai. Jadi iklan standar memiliki tujuan untuk memperoleh keuntungan ekonomi. Iklan layanan masyarakat yaitu iklan yang bersifat non profit. Iklan ini juga sering disebut dengan iklan layanan masyarakat. Keuntungan dari iklan layanan masyarakat adalah berusaha mendapatkan atau memberi citra baik di tengah masyarakat. Pembagian iklan dapat juga didasarkan pada media yang digunakan.

Menurut Rachmadi (2009) iklan adalah pesan atau penawaran suatu produk atau jasa yang ditujukan kepada khalayak lewat media. Pemasang iklan menggunakan pesan itu untuk mendapatkan keuntungan yaitu mempersuasikan calon konsumen sedemikian rupa sehingga calon konsumen akan melakukan apa yang diharapkan pemasang iklan atau membeli produk atau jasa sesuai yang ditawarkan.

Berdasarkan media yang digunakan iklan terbagi atas dua jenis yaitu iklan cetak dan iklan elektronik. Iklan cetak terdiri atas iklan baris, iklan kolom, iklan advetorial, dan iklan display. Iklan baris sering disebut dengan istilah 
iklan kolom atau rubik yang digunakan oleh media yang bersangkutan. Iklan kolom yaitu iklan yang memiliki lebar satu kolom namun lebih tinggi dari iklan baris. Iklan advertorial yaitu iklan yang memiliki ukuran yang luas sebagaimana iklan display, hanya saja teknik penyampaian pesan lebih diarahkan pada bentuk seperti pada sebuah berita dengan naskah yang panjang. Iklan display yaitu iklan yang memiliki ukuran luas dari kolom. Pemasang iklan tinggal memilih luas yang dikehendaki sesuai dengan kebutuhan dan dana yang dialokasikan.

Iklan elektronik terdiri atas iklan radio dan iklan televisi. Iklan radio yaitu iklan yang hanya dapat didengarkan melalui media audio (suara) saja. Iklan televisi yaitu iklan yang mengandung suara, gambar dan gerak (Widyatama, 2009). Berdasarkan uraian di atas iklan di media sosial merupakan iklan elektronik. Hampir sama seperti iklan di televisi karena sama-sama mengandung audio visual. Tetapi cara penampilannya yang berbeda, karena iklan di media sosial dapat melihat produk-produk kosmetik lebih lengkap sedangkan di televisi cuma sekilas dan yang ditampilkan yang penting-penting saja tidak detail.

Iklan adalah membawa pesan yang ingin disampaikan oleh produsen kepada khalayak ramai. Maka dari itu kita harus mengerti apa sesungguhnya fungsi iklan, iklan berfungsi untuk : (1) Menghadapi dan mengatasi kompetisi, (2) Menunjang penjualan dalam jangka waktu pendek dan panjang, (3) Memupuk image, (4) Merebut share of mind, (5) Membuka dan memupuk market segmen baru, (6) Memperkenalkan produk atau jasa kepada masyarakat, (7) Memelihara loyalitas konsumen, (8) Mengatasi naturaldecline, (9) Mempengaruhi keputusan membeli (10) Mendukung usaha promosi, (11) Memberikan patokan terhadap perancangan target produk.

\section{METODE PENELITIAN}

Berdasarkan masalah yang diajukan dalam penelitian ini, yaitu menganalisis karakteristik gaya bahasa dalam wacana iklan produk kosmetik di facebook maka jenis penelitian yang digunakan adalah penelitian deskriptif kualitatif. Pada hakikatnya penelitian kualitatif adalah penelitian yang bermaksud untuk memahami fenomena yang dialami oleh subjek penelitian, misalnya perilaku, persepsi, motivasi dan tindakan, secara holistik dan dengan cara deskripsi dalam bentuk kata-kata dan bahasa pada suatu konteks khusus yang alamiah dengan memanfaatkan berbagai metode ilmiah (Moleong, 2012:6).

Penelitian ini menghasilkan deskripsi berupa kata-kata tertulis atau lisan, bertujuan membuat 
deskripsi (gambaran) secara sistematis, faktual dan akurat mengenai fakta-fakta yang berhubungan antara fenomena yang diteliti. Dengan demikian, hasil penelitian dideskripsikan dengan rangkaian bahasa sesuai hasil analisis dalam fokus penelitian penggunaan kata dan gaya bahasa dalam wacana iklan produk kosmetik di media sosial.

Sumber data diambil dari media sosial yang sekarang sedang dikenali oleh masyarakat Indonesia yaitu facebook. Pemilihan media sosial tersebut karena iklan-iklan yang ditampilkan sekarang sesuai perkembangan zaman dan teknologi yang semakin maju tidak hanya ditayangkan di televisi atau media cetak. Data yang digunakan dalam penelitian ini merupakan data yang diambil dari produk kosmetik di facebook dalam iklan wardah, pond's, maybelline, dan oriflame. Karena produk-produk tersebut sekarang banyak yang cara penjualannya di online kan. Sejak kemunculannya itu hampir semua masyarakat mengenal kosmetik dan selalu mendapatkan respon positif dari masyarakat.

\section{HASIL DAN PEMBAHASAN}

Gaya bahasa merupakan pengaturan kata-kata dan kalimatkalimat oleh penulis atau pembaca dalam mengekspresikan ide, gagasan, dan pengalamannya untuk menyakinkan atau mempengaruhi penyimak atau pembaca. Dalam penelitian ini, gaya bahasa yang diteliti di fokuskan pada jenis gaya bahasa yang berdasarkan struktur kalimat.

Struktur sebuah kalimat dapat dijadikan landasan untuk tempat sebuah unsur kalimat yang dipentingkan dalam kalimat tersebut. Ada kalimat yang bersifat periodik, dan berimbang.

Berdasarkan macam struktur tersebut, diperoleh gaya bahasa sebagai berikut :

\section{Klimaks}

Klimaks merupakan gaya bahasa yang mengandung urutanurutan pikiran yang semakin meningkat kepentingannya dari gagasan sebelumnya. Adapun analisis klimaks sebagai berikut :

(1) Tertarik untuk tampil percaya diri tanpa bekas luka dan keloid? Bekas caesar, operasi, luka bakar, luka tergores, luka jahitan atau luka bekas jerawat bisa kamu pudarkan dengan Keloplast! Lembaran Silicone Gelnya mampu menipiskan benjolan keloidmu dan menyamarkan warna bekas luka dengan sekitar lho. Coba sekarang! 
Data di atas pada iklan produk kosmetik keloplast pada kata "lembaran silicone gel" mengandung gaya bahasa klimaks yang artinya gaya bahasa yang mampu menipiskan benjolan dan menyamarkan bekas luka apapun. Iklan produk tersebut yang paling terbaik dari produk lainnya.

(2) Oriflamers, dua kepribadian yang berbeda akan saling tarik menarik! Begitu juga dengan wewangian dari Incognito for him Eau de Toilette ini. Aroma sensual dari patchouli dan cedar leaves membuat pasangan kamu semakin nyaman berada di dekatmu. Penawaran special bulan ini hanya Rp 179.000 per produk!

Data di atas pada iklan produk kosmetik parfum Oriflame pada kata "Aroma sensual dari patchouli dan cedar leaves" mengandung gaya bahasa klimaks artinya gaya bahasa yang menyatakan bahasa parfum Oriflame mampu membuat pasangan semaakin nyaman di dekatnya. Iklan produk tersebut menggambarkan bahwa Oriflame produk kosmetik yang paling terbaik dari produk lainnya.

(3) Tampil cantik dengan bulu mata tebal kini bukan hanya impian!
Aplikasikan maskara terbaru dari Oriflame, COLOURBOX Fat Mascara. Cukup sekali oles, bulu mata tebal, kini bisa jadi kenyataan!Miliki sekarang hanya 59.900 rupiah saja lho! Jangan sampai kehabisan ya!

Data di atas pada iklan produk kosmetik Oriflame pada kata "COLOURBOX Fat Mascara" mengandung gaya bahasa klimaks artinya gaya bahasa yang menyatakan bahwa produk Oriflame mampu membuat bulu mata menjadi tebal dalam sekali oleh. Iklan produk tersebut menggambarkan bahwa Oriflame produk kosmetik mascara yang paling baik dari produk lainnya.

(4) Giorgino Gold Iconic Lipstick SPF 15 pilihan tepat bagi anda yang ingin tampil dengan bibir berwarna namun tetap lembab mempesona! Koleksi semua warnawarninya dengan harga hanya 139.000 rupiah saja perproduk!

Data di atas pada iklan produk kosmetik Oriflame pada kata “Giorgino Gold Iconic Lipstick SPF 15 " mengandung gaya bahasa klimaks artinya gaya bahasa yang menyatakan bahwa lipstick Giorgino Gold mampu membuat 
bibir menjadi mempesona dengan harga yang lebih murah.

(5) Kini hadir Wardah White Secret Pure Treatment Essence! Diformulasikan dengan Puressential Skin Solution yang mengandung Edelweiss Extract, bantu pancarkan cahaya cerah kulitmu. Juga mengandung Silver Vine Extract, Niacinamide dan Skin Awakening System untuk menjaga kulit tetap lembab terhidrasi dan terlihat lebih cerah bercahaya.

Data di atas pada iklan produk kosmetik Wardah pada kata "Diformulasikan dengan Puressential Skin Solution yang mengandung Edelweiss Extract" mengandung gaya bahasa klimaks artinya produk kosmetik tersebut dipercaya mampu memancarkan cahaya cerah dari kulit dan berbeda dengan produk kosmetik lainnya.

(6) Ladies, yuk aplikasikan Wardah Eyexpert Eyeliner series untuk pancaran mata sempurna di setiap kegiatanu. Dengan warna intens, waterproof formula yang halal dan tekstur nyaman untuk tampilan garis mata yang tipis hingga smoke eyes yang maksimal.

Wardah
Eyexpret Eyeliner memberimu berbagai pilihan sesuai kebutuhan dengan eyeliner pencil white ang black, staylast gel eyeliner, staylast liquid eyeliner dan optimum hiblack liner.

Data di atas pada iklan produk kosmetik Wardah pada kata "Wardah EyeExpert Eyeliner" mengandung gaya bahasa klimaks artinya gaya bahasa yang menggunakan sesuatu di setiap kegiatan sehari-hari dengan formula halal dan tekstur nyaman sehingga memberi hasil yang maksimal.

(7) Wardah C-Defense series merupakan rangkaian perawatan kulit dengan Hi-Grade Vitamin C yang tidak hanya merawat kulitmu tapi juga melindunginya dari dampak buruk sinar UV dan radikal bebas. Kulit menjadi lebih segar, tidak kusam, dan terlindungi secara optimal.

Data di atas pada iklan produk kosmetik Wardah pada kata "Wardah C-Defense series" mengandung gaya bahasa klimaks artinya produk kosmetik mengandung vitamin $\mathrm{C}$ yang mampu menyegarkan kulit dan membuat kulit tidak kusam secara optimal. 
(8) Ladies, lengkapi koleksi Lip Color mu dengan 6 warna terbaru Wardah Exclusive Matte Lip Cream. Untuk memenuhi kebutuhanmu, kini Wardah Exclusive Matte Lip Cream hadir dengan formula Colorbinding Pigments terbaru yang menghasilkan warna bibir matte dan intens tanpa menyebabkan bibir kering dengan kandungan Enriched vitamin E di dalamnya.

(9) Untuk ekspresi lembut tidak terlupakan Wardah Exclusive Lipstick warna baru hadir dengan Satin Gloss finish dan color divine pigments untuk senyum menawan mu ladies! Kandungan vit $\mathrm{E}$ dan squalane yang halal membuat setiap olesan Wardah Exclusive Lipstick terasa halus dan lembab. Hiasi setiap kesempatan dengan warna lembut andalan Wardah Exclusive Lipstick.

Data di atas pada iklan produk kosmetik Wardah pada kata "Wardah Exclusive Matte Lip Cream dan Wardah Exclusive Lipstick" mengandung gaya bahasa klimaks yang menyatakan bahwa lipstik wardah yang memang benar bisa mmenghasilkan warna yang bagus dan tidak menyebabkan bibir kering. Sehingga bisa tampil percaya diri dengan senyum yang menawan.

(10) Pond's Magic Powder Pinkish White Glow ini bikin wajahmu cerah dan bercahaya bahkan di bawah matahari! Bedak ini melindungi dan membuat kulit wajahmu dewy finish dan glowing saat liburan!

Data di atas pada iklan produk kosmetik Pond's pada kata "Pond's Magic Powder Pinkish White Glow" mengandung gaya bahasa klimaks yang menyatakan bahasa Glow mampu menghasilkan bedak yang melindungi kulit wajah dari matahari dan wajah tetap terlihat glowing.

\section{Antiklimaks}

Antiklimaks merupakan suatu acuan yang gagasannya diurutkan dari yang terpenting ke gagasan yang kurang penting. Adapun analisis data yang antiklimaks sebagai berikut :

(11) The color of total happyness with elegant red of Wardah Exclisive Lipstick Sadwe 35 dan 53. Warna merah andalan untuk ekspresi lembut tidak terlupakan ladies! 
Data di atas pada iklan produk kosmetik lipstik Wardah pada kata "Wardah Exclisive Lipstick Sadwe" mengandung gaya bahasa antiklimaks, menyatakan bahwa sesuatu yang sudah ditentukan pada awal nomor seri lipstik tidak perlu diulang karena akan menjadi tidak berguna. Nomor tersebut sudah termasuk penjelas untuk konsumen yang ingin membeli lipstik.

(12) Yuk jangan lupa untuk terus pake pond's faciol foam setiap kali kamu cuci muka dan pond's mousturizer untuk mencerahkan wajah kamu!

Data di atas pada iklan produk kosmetik sabun Pond's pada kata "Pond's Faciol Foam" mengandung gaya bahasa antiklimaks, menyatakan bahwa sabun tersebut tidak dijelaskan kandungan yang tertera, jadi takut beresiko pada konsumen yang memakai.

(13) Dengan hasil yang pigmented, 4 warna pilihan dari maybelline lint bisa jadi pilihan tepat untuk make up kamu di pagi maupun malam hari. Try, baebellines?

Data di atas pada iklan produk kosmetik Maybelline pada kata "maybelline lint" mengandung gaya bahasa antiklimaks, menyatakan bahwa bahasa yang dipakai tidak jelas apa yang dimaksud, karena data tersebut tanpa menjelaskan produknya secara rinci.

\section{Repetisi}

Repetisi

merupakan pengulangan bunyi, suku kata, kata atau bagian kalimat yang dianggap penting untuk memberikan tekanan dalam sebuah konteks yang sesuai. Di bawah ini analisis yang sesuai dengan repetisi sebagai berikut :

(14) Madu dan susu dikenal sebagai bahan alami yang melegenda untuk merawat kecantikan kulit, menjadikannya tampak segar dan terus bersinar. Manjakan kulitmu dalam inspirasi legenda madu dan susu dengan keharuman mewahnya yang ikonik bersama Milk \& Honey Gold Moisturising Shower Cream, Milk \& Honey Gold Liquid Hand Soap, dan Milk \& Honey Gold Smoothing Sugar Scrub!

Data di atas termasuk pada iklan produk kosmetik sabun, mengandung gaya bahasa Repetisi pada kata "madu dan susu". Merupakan pengulangan kata baik suku kata maupun kata pada kalimat dengan memberi penekanan agar kalimat tersebut mudah diingat 
dan para konsumen akan teringat oleh produk kosmetik yang ditawarkan.

$$
\begin{aligned}
& \text { Giordani Gold } \\
& \text { Essenzaparfum adalah } \\
& \text { puncak keindahan } \\
& \text { wewangian dengan } \\
& \text { kemewahan sejati bagi } \\
& \text { perempuan yang } \\
& \text { menghargai hidup dan } \\
& \text { keindahan didalamnya. } \\
& \text { Dibuat dengan sentuhan } \\
& \text { mewah Orange Blossom } \\
& \text { Essenza dari Oriflame, }
\end{aligned}
$$

Giordani Gold

Data di atas termasuk pada iklan produk kosmetik parfu, mengandung gaya bahasa Repetisi pada kata "Giordani Gold Essenza" dan kata "keindahan". Merupakan pengulangan kata baik suku kata maupun kata pada kalimat dengan memberi penekanan agar kalimat tersebut mudah diingat dan para konsumen akan teringat oleh produk kosmetik parfum dari Giordani Gold Essenza yang memberi keindahan dan kemewahan lewat botol kacanya.

(16) Kulit kusam, gelap dan mulai ada kerutan? No worry... gunakan iFACEVitamin C Serum secara rutin dan teratur, efektif cerahkan kembali kulit kusam dan samarkan kerutan, wajah tampak selalu muda. Vitamin C for My Face iFACE.

Data di atas termasuk pada iklan produk kosmetik sabun, mengandung gaya bahasa Repetisi pada kata "kerutan" dan "i-Face". Merupakan pengulangan kata baik suku kata maupun kata pada kalimat dengan memberi penekanan agar kalimat tersebut mudah diingat dan para konsumen kalau kulit wajahnya terdapat kerutan harus memakai produk kosmetik $i$-Face.

(17) Ladies, ingin kulit wajahmu terlihat cerah bebas kilap? Pakai bedak tapi tetap terlihat natural dan ringan dipakai sehari-hari? Wardah Lightening BB cake powder solusinya! Bedak padat dengan hasil natural untuk menghaluskan kulit dan ringan untuk dipakai sehari-hari. Mengandung SPF 15 pa++ dengan oil balancing beads dan lightfilter fillers yang membuat kulit wajah normal berminyak tampak bebas kilap, matte, dan cerah sepanjang hari. 
Data di atas termasuk pada iklan produk kosmetik bedak, mengandung gaya bahasa Repetisi pada kata "bebas kilap" dan "sehari-hari". Merupakan pengulangan kata baik suku kata maupun kata pada kalimat dengan memberi penekanan agar kalimat tersebut mudah diingat dan para konsumen ingin wajah yang bebas kilap setiap hari dan terlihat natural, harus memakai Wardah Lightening BB Cake Powder.

(18) Banyak yang bilang kalau bekas jerawat itu susah hilang? Sekarang bekas jerawat kamu bisa hilang lebih cepat dengan menggunakan pond's white beauty untuk kulit berminyak. Kandungan vitamin B3+ dan spot white technology-nya samarkan noda bekas jerawat $3 x$ lebih cepat. Jadi vaceready dengan wajah tampak putih merona, mulus dan noda tersamarkan.

Data di atas termasuk pada iklan produk kosmetik Pond's, mengandung gaya bahasa Repetisi pada kata "bekas jerawat". Merupakan pengulangan kata baik suku kata maupun kata pada kalimat dengan memberi penekanan agar kalimat tersebut mudah diingat dan para konsumen jika ingin menghilangkan bekas jerawat dengan cepat bisa menggunakan Pond's White Beauty.

\section{SIMPULAN}

Gaya bahasa yang digunakan dalam iklan produk kosmetik di media sosial memakai gaya bahasa yang fokus pada segi bahasa. Pemakaian gaya bahasa dilihat dari segi bahasa berdasarkan struktur kalimat dalam penelitian ini difokuskan pada klimaks, antiklimaks, dan repetisi.

\section{DAFTAR PUSTAKA}

Keraf, Gorys. (2008). Diksi dan Gaya Bahasa. Jakarta. PT. Gramedia Pustaka Utama

Kridalaksana, Harimurti. (2001). Kamus Linguistik. Jakarta: Gramedia

Meleong. (2005). Metodologi Kualitatif Edisi Revisi. Bandung: PT Remaja Rosdakarya

Rachmadi. (2009). Public Relation dalam Teori dan Praktek. Jakarta : Gramedia.

Tarigan, Henry Guntur. (2013). Pengajaran Gaya Bahasa. Bandung: Angkasa

Widyatama, Rendra. (2009). Pengantar Periklanan. Jakarta Pusat: Buana Pustaka Indonesia. 
